\title{
Reflection of Social Reality in the Context of the Legal Discourse of Russian Literature: Research Specificity and Objectives
}

\author{
Elena Skorohodova \\ Natalia Shutaya \\ Oksana Lytkina \\ Anastasia Rudnitskaya \\ Larisa Mishina
}

Russian State Social University, Russia, Moscow, 129226, V.Pika 4

Doi:10.5901/mjss.2015.v6n5s2p290

\begin{abstract}
The article outlines the object of interdisciplinary research - legal discourse of Russian literature, the urgency of its study, defined methodology and main objectives of his research, the analysis of the perspectives of social reality, the consciousness of Russians and philosophical issues in the context of legal discourse of Russian literature.
\end{abstract}

Keywords: discourse, legal discourse, concept, metaphor, picture of the world, chronotope, social reality, the sense of justice, national mentality.

The most important task of literary works of art is the true rendering of social and philosophical issues of the era the author lives in.

An important aspect of social reality is law as the people's special relationship system, involving the recognition of rights and duties of the people (redundant; and not only people to be exact), the responsibility for non-submission to the law and the legitimate authority, a certain management order, as well as the existence of special institutions for the maintenance of order and the rule of law court, police, correction institutions, etc. Despite the differences in the people's legal conscience, the basis for various national legal systems is always made of the idea of justice, law and order.

Of all kinds of art as an artistic display of reality, literature is most suitable for the legal discourse implementation. Research on the legal discourse of Russian literature will contribute to deeper understanding of the Russian legal consciousness peculiarities, as well as indirectly improve the legal culture of modern Russians.

It must be recognized that the legal discourse of literature is not studied enough now: the scientific works that specifically address this aspect of literature are missing, although there are works that reveal important aspects of its study (Golyakov, 1956; Koni, 1900).

This runs counter to the need of studying the characteristics of the Russians' legal consciousness as an essential component of the national mentality, as well as the further development of the discourse theory. Therefore, the relevance of the study, which is aimed at resolving this contradiction, is of no doubt: the study of legal discourse is relevant both in theoretical and practical terms.

Representative works of Russian classic literature of the 19th century serve as the empirical base of the research. These works represent the author's dominating realistic recreation of the historical and contemporary social reality; at this, it is also important that there is relative proximity of these images' thinking mentality to the modern Russians' way of thinking.

\section{Methods}

\subsection{Discourse as main research category}

Let's specify that discourse is an interdisciplinary category (Stepanov, 1995; Tarasova, 2010). In a philosophical context, discourse refers to socially bound speech system (Foucault, 1996; Kozhina, 2004). From the perspective of 
sociolinguistics, discourse is described as "a set of statements that make up any divided speech event, for example, a talk, a joke, a sermon, an interview" (Crystal, 2003), as a "communion of persons, considered from the perspective of their membership in a particular social group, or concerning a typical speech-behaviour situation, for example, institutional communication "(Karasik, 2004) as a "form of social action" (Fairlough, 1997). Accordingly, the study of discourse, in broad terms, shall be regarded as a "critical linguistics branch, which studies the relationship between discourse events and socio political and cultural factors" (Crystal, 2003). From the point of view of a narrower linguistic approach, discourse is matched against text like a dialogue against a monologue (Makarov, 2003; Arutyunova, 1990), and many linguists emphasize the connection between discourse and the communicative situation (Arutyunova, 1990) and the actual process of communication. T. van Dejk characterizes discourse as "a complex communicative event" (van Dejk, 2006; Dejk T, 1998), which is realized at the micro social level, displaying the collective representation of reality.

This article defines the basic objectives of the legal discourse research of classical Russian literature.

\subsection{The analysis objectives of the legal discourse concepts in the classical Russian literature}

All the concepts of law discourse can be represented as a set of semantic and thematic fields in accordance with the content of the law regulated social relations (Lytkina, 2010) by highlighting the following concepts groups.

First, the concepts, expressing the civil legal relations: ownership, inheritance, transaction, treaty, obligations, civil responsibility, etc., that is, the scope of civil law. This group includes, as relatively independent sub-groups, the concepts, expressing the family (husband and wife, parents and children, family estate, dowry, inheritance, wills, divorce, custody, etc.), as well as concepts, expressing the employment (working hours, working conditions, remuneration, etc.)

Secondly, the concepts, expressing relations, connected with governance and the maintenance of public order, that is, the scope of administrative law: police, policeman, table of ranks, department, bosses, etc.

Thirdly, the concepts, expressing the relations connected with criminal prosecution for committed crimes: police investigation, courts, crime, punishment, prisoner, penal colony, etc.

Fourthly, the concepts that express the idea of higher public authorities: autocracy, law, sovereign, oath, rebellion (revolution), etc.

Fifthly, concepts, expressing relations of personal dependence (in conditions of serfdom), specific for Russia in the first half of the 19th century: landlord, castle servant, serf peasant, "freedom" (gained by the former serfs after the abolition of serfdom), etc. The presence of these concepts in the legal discourse of classical Russian literature makes its specific feature.

All of the groups of legal concepts are also presented in the works of classical Russian literature. This means that, at least at the level of conceptualization, the legal discourse of Russian classical literature is sufficiently developed. It conceptualized all objectively existing types and kinds of legal relations, including the specific features of the Russian Empire legal system.

However, already at the level of concepts composition, one can notice some specific features of the classical Russian literature legal discourse. Thus, the concepts of civil legal relations are relatively rarely used in it, in comparison, for example, with the English literature.

When analyzing legal concepts in the discourse of classical Russian literature, it is important to take into account not only the main concepts, their hierarchy by importance and frequency of use, but also their moral connotation. In this regard, all of the legal concepts used in the works of the classical Russian literature can be divided into positively connotative, negatively connotative, neutral in value and ambivalent in value. These characteristics can be identified both at the level of individual works of fiction, and at the level of legal discourse of classical Russian literature in general.

As a result of the analysis, an interesting peculiarity is found: the lack of absolutely positively connotative legal concepts of law discourse in the classical Russian literature. For each of the legal concepts with predominantly positive connotations, you can find an example or several examples of works in which it is represented with a negative connotation. For example, for A.S.Pushkin, N.V. Gogol, S.T. Aksakov and other Russian writers of the 19th century, marriage is certainly a positively connotative concept, while the novels of Leo Tolstoy "Anna Karenina" and "War and World", "Kreuzer Sonata" show the examples of naturally unhappy and disintegrating marriage, the value of marriage itself is in question, the value connotation of the concept is at least ambivalent, if not outright negative.

However, absolutely negatively connotative legal concepts can be found. These include, in particular, all the concepts related to the criminal punishment for crimes (imprisonment, hard labour camp, penalty, sending out of the country, etc.). The negative assessment applies not only to the penalty but to the crime too.

In general, the legal discourse of classical Russian literature is characterized by a significant prevalence of negative and ambivalent connotations of legal concepts over the positive ones. This may be a sign that the Russian 
national consciousness aspires to build relations on the principles of trust and love, not requiring legal regulation. This thesis presents a hypothesis, which proof is one of the objectives of the study of classical Russian literature legal discourse.

\subsection{Tasks of analysis of categories of the classical Russian literature legal discourse}

By means of the above-described concepts, the fundamental categories of law discourse of classical Russian literature are expressed. At this, most categories of this discourse like concepts reveal their ambivalence, being parts of different binary oppositions. Thus, the category of "Freedom", depending on the certain plot context, may have such opposite poles as "Coercion", "Violence" and even "Lawlessness" (A.S. Pushkin. Ode "Liberty") or "Fidelity", "Liability", "Honour" (A.S. Pushkin. "Captain's daughter", "Gypsies"). In the first case, the antithesis of freedom is the outer limitation, while in the second it is the internal limitation. Category 'Order ' has the opposite pole of "Chaos" or it can be "Life" (F.M. Dostoevsky "White Nights", "The tamed one"). The category "Equity" can be opposed not only by the "Injustice", but also by "Love" ("L. N. Tolstoy "Anna Karenina"). Thus, the categories of classical Russian literature legal discourse, as well as the concepts do not have any rigid and unambiguous ethical connotation. The binary oppositions realized through the plot reveal their ambivalence. It should also be noted that the system of categories of this discourse is open, it closes through oppositions meeting ends with external categories, which are not specific for this discourse.

Axis of this system binary opposition is the opposition "Truth-Falsehood", where "Truth" is not only justice and legitimacy, but also honesty, adherence to the policy of good and justice standards. "Falsehood" (this term is used for lack of a better meaning) refers to lies, deliberate lawlessness, injustice and inhumanity of those in power, as well as the hypocritical concealment of crimes and vices.

It is important to note that this binary opposition is not specifically law-related. The category of "Truth" and "Falsehood" are semantically syncretic, connecting the legal and moral judgment into the unbreakable unity.

The further research on the system of categories of classical Russian literature law discourse aims at its full recreation, taking into account the internal linkages.

\subsection{Research objectives concerning the metaphors of the classical Russian literature legal discourse}

Above we mentioned the court metaphor, which is important for the whole European culture (Rafaelov L.M., 2013). But while in the Western European culture in general, the concept "Court/Trial" metaphorically expresses, above all, the idea of Justice triumph, in the context of classical Russian literature legal discourse, the Court /Trial metaphor along with this semantic element, actively actualizes the elements of confession and incrimination. The Court in this type of discourse is the time and place when and where everything secret hitherto hidden in the human soul, becomes obvious. This is how the Court metaphor is used in F.M. Dostoevsky's novels ("Crime and punishment", "Karamazov Brothers"). Nevertheless, Russian writers also actively use the traditional European version of metaphorical "court/trial" concept often "a contrario"creating images of unrighteous court, which flouts the rules of justice and law. This is the court, depicted in the "Dubrovsky" story by Pushkin, so is the trial of Katyusha Maslova in the novel by Leo Tolstoy "Voskresenie" ("Resurrection"). The Russian writer sees the perversity of this trial not so much in the retreat from the truth or the law, but in lack of mercy, in soulless trampling of the human, mechanical indifference to the person and her fate.

Along with the concept of "Court/Trial" other concepts of legal discourse, in particular, the concept "Deal/Agreement" also become the material for metaphorization. It is worth recalling, that in the civil law, a contract is a type of transaction, namely, a third-party transaction. In the context of the classical Russian literature legal discourse, this metaphor has a high level of abstraction. "The Deal" (the "Agreement") is one of the concepts, the primary meaning of which lies in the sphere of civil relations. This relationship, as noted before, is not in the focus of classical Russian literature attention and the concepts, expressing it, are often used not in their direct meanings.

This is true about this concept, characterized by rather metaphorical use in the meaning "deal with the conscience" (A.I. Goncharov "A usual story"), "deal with the devil" (N.V. Gogol «Portrait»). Through the metaphorization, the concept reveals its intrinsic antinomy: on the one hand, a contract is the guarantee of reliability, the parties' intentions stability, loyalty to the given word. On the other hand, strict adherence to the letter of the Treaty could lead to the negation of the values for which it was concluded, and can be used for evil by the dishonest party, what is illustrated by Sheylock (Shakespeare 'The merchant of Venice'). We shall note that in the Russian language the words "a deal", "a businessman" have negative connotations in the everyday usage.

Along with these described two concepts, there are other legal concepts used in classical Russian literature in the metaphorical function. These are, for example, 'Prison' (M.Y.Lermontov. Poem "Prisoner"), "Katorga" (concentration 
camp) (F.M. Dostoevsky 'Notes from the House of the Dead") and others. It is not difficult to see that these concepts relate to the concepts used in all ages as "indicators of social and business activity" (Kryachko, 2012). Such concepts are "equity" (Butova and Kryachko, 2013), "mercy" (Nikitina, 2014), "faith" (Talapova, 2006).

The further study of metaphors of the classical Russian literature legal discourse aims at identification and description of the key metaphors of this discourse, as well as the peculiarities of metaphorization typical of this discourse.

\subsection{Objectives of study of classical Russian literature legal discourse peculiarities, associated with the artistic form of the literary work}

We should recall that the concepts, expressing the civil legal relations are relatively rarely used in the legal discourse of Russian literature, in comparison with, for example, English literature. But it is not only and not even so much about the quality proportion of their connection with the work's storyline and plot. If the English novel quite often demonstrates the intrigue associated with debt obligations (novels by G. Fielding, Ch. Dickens), wills, inheritance, contract ('The merchant of Venice' by W. Shakespeare), the array of classic Russian literature doesn't have so many works of this kind. Examples of such works are: "Teenager" by F.M. Dostoyevsky, in which the source of one of the plot intrigues, is the existence of "a compromising letter» of Katerina Nikolaevna, which showed her intention to limit the legal capacity and take care of their mentally-ill father to protect him and herself from bankruptcy. Although this civil-legal collision constitutes a problem for the novel heroine, it is very indirectly linked with the themes of the novel and is not involved in the formation of its problems. A textbook example of civil legal fact used in the story plot construction, without a hint of any participation in constituting themes and problems, is the beginning of A.S. Pushkin's verse novel 'Eugene Onegin': Onegin inherits his uncle's estate, for this reason, he goes to the village and becomes a neighbor of the Larins. However, the fact of inheritance does not play any more role the further novel plot.

\section{Discussion}

The study of the classical Russian literature legal discourse aims at identifying its characteristics and internal rules related to such means of expression, as genre, storyline and plot, figurative system of the work, including the main character image, his environment and micro-environment, specific symbols, artistic time and space.

So, for example, among the legal discourse elements we can name chronotope of the ordinary court places characterized by the factors, previously identified by Y. M. Lotman, which contribute to the hero suffering idle mood and boredom, which lead to self-communication It is worth emphasizing that this chronotope (Shutaya, 2005) sets the conditions for such human interaction in which people lose the ability to perceive pain and suffering of another human being.

This chronotope includes a mechanism, which generates plot development in specific patterns: Persecutors mock the victim and triumph over it in the official place; the victim tries to protest; one of the persecutors feels remorse or pity and departs from other persecutors. This predictable pattern, for example, is expressed in such novels as "Dubrovsky" by A.S. Pushkin, "Resurrection" by L. N. Tolstoy.

\section{Results}

The result of the conducted study is the development of guidelines and setting targets for the further research of the classical Russian literature legal discourse.

On the one hand, the main directions of the research are explained by the structure of the study object-the legal discourse of classical Russian literature, on the other hand-by the methodology of the study. The main directions of further research include, first, the further development of the theoretical-methodological and analytical apparatus. Secondly, it is the literary analysis of the classical Russian literature works in terms of identifying features of the legal discourse. Thirdly, the construction of the generalizing theoretical models of individual components of the classic Russian literature legal discourse and, on their basis, holistic models of research object. Fourthly, interpretation of the research results of in a broad sociocultural context, developing practical recommendations for the development of modern Russians' legal awareness using materials of classical Russian literature.

\section{Conclusion}

Here are the research objectives concerning the legal discourse of classical Russian literature: 
- construction of a systematic description of the legal discourse concepts, in view of the initial drawing up profiles of these concepts;

- verification of the hypothesis that the Russian national mentality is characterized by the desire to build relationships based on trust and love, not requiring any legal regulation, which explains the absence of absolutely positive connotations of legal concepts in the presence of absolutely negative connotations of legal concepts in the legal discourse of classical Russian literature, as well as the total predominance of negative and ambivalent connotation of the legal concepts over their positive connotation;

- construction of a theoretical model of system of categories of classical Russian literature legal discourse, taking into account the semantic and structural relationships between the categories;

- identifying and describing the key metaphors in legal discourse of classical Russian literature, as well as its specific features of the metaphorization;

- identification of the characteristics and internal patterns of classical Russian literature legal discourse, realized by using specific means of expressiveness in literature, such as genre, theme and problem, story and plot, composition, imagery system of the work, including the image of the main character, his environment and its micro-environments, specific symbols, artistic time and space, chronotope.

\section{References}

Crystal, D.A. (2003) Dictionary of Linguistics and Phonetics / D.A. Crystal. - London: Blackwell Publishing

Dejk, T.A. van (2006) Discourse and Manipulation. Discourse \& Society. - SAGE Publications

Dejk, Van T. (1998) Ideology: A Multidisciplinary Approach. London: Sage

Fairlough, N. (1997) Critical Discourse Analysis. A Multidisciplinary Introduction. Discourse as Social Interaction. Discourse Studies (P. 271-280). London: Sage

Arutyunova, N.D. (1990) Discourse. Linguistic encyclopedic dictionary (P. 136-137). M.: Soviet encyclopedia

Butova, A.A. \& Kryachko, V.B. (2013).Concept "justice" in Russian and English linguo-cultures. Almanac of science and education, 7 (74), 23-25

Golyakov, I.T. (1956) Court and the rule of law in the Russian literature of the 19th century. M.: IZD-vo MGU.

Karasik, V.I. (2004). Language circle: Identity, concepts, discourses. M.: Gnosis

Kozhina, M.N. (2004). Discourse analysis and functional stylistics from the speech science positionsll (P. 9-41).Text - Discourse Style: Collection of scientific works. Spb

Connie, A. F. (1900). Pushkin's societal attitudes//Honoring the memory of A.S. Pushkin by the Academy of Sciences in the centenary of his birth. St. Petersburg

Kryachko, V.B. (2012) Word and information: the uncertainty principle. Philological sciences. Questions of theory and practice (p. 46-48). Tambov: Gramota, 3 (14)

Lytkina, O. I. (2010). Types of world views in the representation of a concept. Russian language abroad, 4, 64-67.

Makarov, M.L. (2003). Discourse theory basis. M.: Gnosis

Nikitina, M.Y. (2014). Concept "Mercy" in the Russian language conscience and the writer's idiostyle. Philological sciences. Questions of theory and practice, Gramota, 2, 39-42

Rafaelov, L.M. (2013). Metaphors of trial in culture. Humanities and social sciences, 2, 275-283.

Stepanov, U.S. (1995). The alternate world, Discourse. The fact and the principle of Causality. Language and science at the end of the 20th century: collection of art. M.: RSTU

Talapova, T.A. (2006). Concept "belief-disbelief" in the aspect of the Russian paremiae. Language, culture, and communication: the aspects of interaction (p. 104-109). Abakan, ISS. 3.

Tarasova, I.A. (2010) Art concept: dialogue of linguistics and literary studies. Bulletin of the Nizhny Novgorod University N.I. Lobachevsky, 4 (2), 742-745.

Foucault, M. (1996). The archaeology of knowledge. Kiev.

Shutaya, N.K. (2005). Plot potential of chronotope "a public place" and their usage in the works of 19th century Russian classics. (on the example of the prose works of Pushkin, Gogol, Tolstoy). Bulletin of Moscow University Issue. 9 (P. 64-75). Philology, 5. 